\title{
Addressing human pressures upon marine mammals: a European and global perspective
}

\author{
PETER G.H. EVANS ${ }^{1,2}$ AND PIA ANDERWALD ${ }^{3}$ \\ ${ }^{1}$ Sea Watch Foundation, Ewyn y Don, Bull Bay, Amlwch, Anglesey LL68 9SD, UK, ${ }^{2}$ School of Ocean Sciences, University of Bangor, \\ Menai Bridge, Anglesey LL59 5AB, UK, ${ }^{3}$ Swiss National Park, Chastè Planta-Wildenberg, 7530 Zernez, Switzerland
}

The last half-century has seen a growing awareness of the impacts that human society has had, and continues to have, upon the environment and the wildlife that live in it. The damage to wildlife from pesticide use and widespread rain forest destruction in the terrestrial environment, overexploitation of fish stocks, and the decline of the great whales from whaling in the marine environment, were some of the more notable issues recognized over this period. 'Save the Whale' campaigns started in the 1960 s by environmental groups around the world. This public pressure led to an international moratorium on whaling recommended in 1972 by the United Nations Conference on the Human Environment in Stockholm, Sweden, and eventually adopted by the International Whaling Commission 10 years later. In the last three decades of the 2oth century, various global conventions for environmental protection were established, including the MARPOL Agreement (1973/78) for control of marine pollution; UNCLOS (1982) - the UN Convention on the Law of the Sea; and the Earth Summit (1992) - the Convention on Biological Diversity, held in Rio de Janeiro.

In Europe, specific regional agreements were established, including (1) OSPAR - The Oslo Paris Convention for the Protection of the Marine Environment of the North-East Atlantic (1992); (2) HELCOM - The Helsinki Convention on the Protection of the Marine Environment in the Baltic Sea Area (1992); (3) The Barcelona Convention for the Protection of Marine Environment and the Coastal Region of the Mediterranean (1995); and (4) The Bucharest Convention for the Protection of the Black Sea (1992). Specifically for cetaceans, the 'Agreement on the Conservation of Small Cetaceans of the Baltic and North Sea' (ASCOBANS) (1992), and the 'Agreement on the Conservation of Cetaceans of the Black Sea, Mediterranean Sea and Contiguous Atlantic Area' (ACCOBAMS) (1996), within the Bonn Convention - the Convention on Conservation of Migratory Species of Wild Animals (1979) are the most important. In February 2008, an extension of

Corresponding author:

P.G.H. Evans

Email: peter.evans@bangor.ac.uk the ASCOBANS agreement area came into force, resulting in a change of name to 'Agreement on the Conservation of Small Cetaceans of the Baltic, North East Atlantic, Irish and North Seas'.

The cornerstone of nature conservation in Europe is the EU Habitats (\& Species) Directive (1992). It is built around two pillars: a strict system for species protection and the Natura 2000 network of protected sites. All cetaceans occurring in Europe are listed in Annex IV of the Directive, requiring strict protection. Two species, the harbour porpoise Phocoena phocoena and bottlenose dolphin Tursiops truncatus, are additionally listed in Annex II, requiring the development of Special Areas of Conservation, where appropriate, as part of the Natura 2000 network. More recently, in 2008, the EU Marine Strategy Framework Directive (MSFD) was adopted by the European Union. The MSFD requires Member States to put in place measures to achieve or maintain Good Environmental Status (GES) by 2020 through the development of national Marine Strategies. In order to achieve GES in a coherent and strategic manner, the MSFD has established four European Marine Regions, based on geographic and environmental criteria. The North-East Atlantic Marine Region is divided into four subregions. Each Member State is required to develop a marine strategy for its waters, in coordination with other countries within the same marine region or subregion. This coordination is to be achieved through the Regional Seas Conventions (HELCOM, OSPAR, Barcelona Convention, Black Sea Convention).

The MSFD does not state a specific programme of measures that Member States should adopt to achieve GES, except for the establishment of Marine Protected Areas (MPAs). It does, however, outline 11 high level descriptors of GES in Annex I of the Directive. Several of these descriptors are relevant to marine mammals, the most obvious ones being Descriptor 1 (biological diversity), Descriptor 3 (food webs), Descriptor 8 (contaminants), Descriptor 10 (marine litter) and Descriptor 11 (noise). Common Indicators have also been established. Those of greatest relevance here include abundance at the relevant temporal and spatial scale of seal and cetacean species regularly present, distributional range and pattern of seal and cetacean species regularly present, harbour seal Phoca vitulina and grey seal Halichoerus grypus 
pup production, and number of individuals within species being by-caught in relation to the population.

Growing out of concern for the apparent declining status across Europe of the harbour porpoise, the European Cetacean Society (ECS) was formed in 1987, with the aim of promoting research and conservation of all marine mammals in European seas. Since the last JMBA Special Issue on marine mammals, the ECS has held two international conferences. The 28th annual conference took place on 5-9 April 2014 in Liège, Belgium on the theme 'Marine mammals as sentinels of a changing environment'; and the 29th annual conference took place on 23-25 March 2015 in St Julians, Malta, on the theme 'Marine mammal conservation from local to global'. In the three decades since its inception, probably the most important contribution the society has made to marine mammal research and conservation is to bring together enthusiasts across Europe, promoting a wide range of collaborative projects. This has seen an exponential growth in papers on different aspects of marine mammal research - abundance surveys and monitoring of trends, behavioural and ecological studies, national stranding schemes and post-mortem studies, investigations into genetics, anatomy, physiology and diet, as well as much emphasis upon the impacts of human activities upon different species.

Has all this attention to marine mammals resulted in the world becoming a safer place for them, or have we been unable to keep pace with human pressures? The answer is rather mixed. On the positive side, there is much greater awareness of the issues involved, and some better understanding of impacts; direct exploitation of marine mammals has largely ceased; and surveys and monitoring are becoming more routine. Some populations appear to be holding their own or even increasing (see, for example, Hammond et al., 2013). On the other hand, one species, the baiji or Yangtze River dolphin Lipotes vexillifer, appears to be extinct (Smith et al., 2008) and another, the vaquita Phocoena sinus, confined to the Gulf of California, is nearing extinction (Rojas-Bracho et al., 2008). And many of the threats that marine mammals face, are still present if not increasing. Vessels are getting faster, increasing the dangers of ship strike (Laist et al., 2001; Pesante et al., 2002; Evans, 2003; Vanderlaan \& Taggart, 2007; Vanderlaan et al., 2008; Evans et al., 2010). Ambient noise levels in the ocean are increasing (NOAA, 2005; Andrew et al., 2011; Tyack et al., 2015), with shipping, seismic exploration, pile driving and active sonar all identified as having potential negative impacts (Evans, 2015). By-catch remains a global issue affecting almost every marine mammal species on earth, and in Europe continues to be a significant issue for species such as harbour porpoise, common dolphin Delphinus delphis and striped dolphin Stenella coeruleoalba, as well as for baleen whales such as minke Balaenoptera acutorostrata and humpback whale Megaptera novaeangliae (Northridge, 1984, 1991; Johnson et al., 2005; Northridge et al., 2010; Reeves et al., 2013; ICES WGBYC, 2015). Despite bans on the production of a number of harmful contaminants such as PCBs, many of these still circulate in the environment, resulting in comparatively high loads in a number of species such as harbour porpoise, bottlenose dolphin and killer whale Orcinus orca (O'Shea, 1999; Reijnders et al., 1999; Evans, 2014; Jepson et al., 2016). And most recently, attention has turned to the implications of climate change for marine mammals, with arctic species such as polar bear Ursus maritimus, ringed seal Pusa hispida and narwhal Monodon monoceros identified as particularly vulnerable (Tynan \& DeMaster, 1997; Würsig et al., 2002; Learmonth et al., 2006; Huntington \& Moore, 2008; Kovacs \& Lyderson, 2008; Kaschner et al., 2011; Evans \& Bjørge, 2013).

In many cases we have the knowledge to tackle these conservation issues. It remains to be seen whether society has the will and resources to do so.

\section{REFERENCES}

Andrew R.K., Howe B.M. and Mercer J.A. (2011) Longtime trends in ship traffic noise for four sites off the North American West Coast. Journal of the Acoustical Society of America 129, 642-651.

Evans P.G.H. (2003) Shipping as a possible source of disturbance to cetaceans in the ASCOBANS region. ASCOBANS 4th Meeting of the Parties, Esbjerg, Denmark, 19-22 August 2003. Document MOP4/ Doc. $17(\mathrm{~S}) .88 \mathrm{pp}$.

Evans P.G.H. (ed.) (2014) Chemical pollution and marine mammals. Proceedings of the ECS/ASCOBANS/ACCOBAMS Joint Workshop, held at the European Cetacean Society's 25th Annual Conference, Cadiz, Spain, 20 March 2011. ECS Special Publication Series No. 55. $93 \mathrm{pp}$.

Evans P.G.H. (ed.) (2015) Introducing noise into the marine environment - what are the requirements for an impact assessment for marine mammals? Proceedings of an ECS/ASCOBANS/ACCOBAMS Joint Workshop held at the 28th Annual Conference of the European Cetacean Society, Liège, Belgium, 6 April 2014. ECS Special Publication Series No. 58. 113 pp.

Evans P.G.H., Baines M.E. and Anderwald P. (2010) Risk assessment of potential conflicts between shipping and cetaceans in the ASCOBANS Region. ASCOBANS AC17/Doc. 6-06 (S). 28 pp.

Evans P.G.H. and Bjørge A. (2013) Impacts of climate change on marine mammals. In Marine Climate Change Impacts Partnership (MCCIP) Science Review 2013, pp. 134-148. doi: 10.14465/2013.arc15.134-148.

Hammond P.S., MacLeod K., Berggren P., Borchers D.L., Burt M.L., Cañadas A., Desportes G., Donovan G.P., Gilles A., Gillespie D., Gordon J., Hiby L., Kuklik I., Leaper R., Lehnert K., Leopold M., Lovell P., Øien N., Paxton C.G.M., Ridoux V., Rogan E., Samarra F., Scheidat M., Sequeira M., Siebert U., Skov H., Swift R., Tasker M.L., Teilmann J., Van Canneyt O. and Vázquez J.A. (2013) Cetacean abundance and distribution in European Atlantic shelf waters to inform conservation and management. Biological Conservation 164, 107-122.

Huntington H.P. and Moore S.E. (eds) (2008) Arctic marine mammals and climate change. Ecological Applications 18 (suppl.), $\mathrm{S}_{1}-\mathrm{S}_{174}$.

ICES WGBYC (2015) Report of the Working Group on Bycatch of Protected Species (WGBYC 2015). ICES CM 2015/ACOM, p. 26.

Jepson P.D., Deaville R., Barber J.L., Aguilar A., Borrell A., Murphy S., Barry J., Brownlow A., Barnett J., Berrow S., Cunningham A.A., Davison N.J., ten Doeschate M., Esteban R., Ferreira M., Foote A.D., Genov T., Giménez J., Loveridge J., Llavona A., Martin V., Maxwell D.L., Papachlimitzou A., Penrose R., Perkins M.W., Smith B., de Stephanis R., Tregenza N., Verborgh P., Fernandez A. and Law R.J. (2016) PCB pollution continues to impact populations of orcas and other dolphins in European waters. Nature Scientific Reports 6, 18573. doi: 10.1038/srep18573.

Johnson A., Salvador G., Kenney J., Robbins J., Kraus S., Landry S. and Clapham P. (2005) Fishing gear involved in entanglements of right and humpback whales. Marine Mammal Science 21, 635-645. 
Kaschner K., Tittensor D.P., Ready J., Gerrodette T. and Worm B. (2011) Current and future patterns of global marine mammal biodiversity. PLoS ONE 6, e19653. doi: 10.1371/journal.pone.0019653.

Kovacs K.M. and Lyderson C. (2008) Climate change impacts on seals and whales in the North Atlantic Arctic and adjacent shelf seas. Science Progress 92, 117-150.

Laist D.W., Knowlton A.R., Mead J.G., Collet A.S. and Podesta M. (2001) Collisions between ships and great whales. Marine Mammal Science 17, 35-75.

Learmonth J.A., Macleod C.D., Santos M.B., Pierce G.J., Crick H.Q.P. and Robinson R.A. (2006) Potential effects of climate change on marine mammals. Oceanography and Marine Biology 44, 431-464.

National Oceanic and Atmospheric Administration (NOAA) (2005) Shipping noise and marine mammals: a forum for science, management, and technology. Final Report of NOAA International Symposium, 18-19 May 2004, Arlington, VA. 40 pp.

Northridge S.P. (1984) World review of interactions between marine mammals and fisheries. FAO Fisheries Technical Paper, 251. Rome: Food and Agriculture Organization of the United Nations.

Northridge S., Cargill A., Coram A., Mandleberg L., Calderan S. and Reid R. (2010) Entanglement of minke whales in Scottish waters: an investigation into occurrence, causes and mitigation. Contract Report. Final Report to Scottish Government CR/2007/49.

Northridge S.P. (1991) An updated world review of interactions between marine mammals and fisheries. FAO Fisheries Technical Paper 251(suppl.). Rome: Food and Agriculture Organization of the United Nations. $58 \mathrm{pp}$.

O'Shea T.J. (1999) Environmental contaminants and marine mammals. In Reynolds J.E. III and Rommel S.A. (eds) Biology of marine mammals. Washington, DC: Smithsonian Institution Press, pp. 485564.

Pesante G., Panigada S. and Zanardelli M. (eds) (2002) Collisions between cetaceans and vessels: can we find solutions? ECS Newsletter no. 40 (Special Issue). $40 \mathrm{pp}$.

Reeves R.R., McClellan K. and Werner T.B. (2013) Marine mamma bycatch in gillnet and other entangling net fisheries, 1990 to 2011 Endangered Species Research 20, 71-97.
Reijnders P.J.H., Aguilar A. and Donovan G.P. (eds) (1999) Chemical pollutants and cetaceans. Journal of Cetacean Research and Management (Special Issue 1), 1-273.

Rojas-Bracho L., Reeves R.R., Jaramillo-Legorreta A. and Taylor B.L. (2008) Phocoena sinus. In IUCN red list of threatened species 2008 , e.T17028A6735464. http://dx.doi.org/10.2305/IUCN.UK.2008.RLTS. T17028A6735464.en

Smith B.D., Zhou K., Wang D., Reeves R.R., Barlow J., Taylor B.L. and Pitman R. (2008) Lipotes vexillifer. In IUCN red list of threatened species 2008, e.T12119A3322533. http://dx.doi.org/10.2305/IUCN. UK.2008.RLTS.T12119A3322533.en

Tyack P., Frisk G., Boyd I., Urban E. and Seeyave S. (eds) (2015) International quiet ocean experiment science plan. $103 \mathrm{pp}$. http:// www.scor-int.org/IQOE/IQOE_Science_Plan-Final.pdf

Tynan C. and DeMaster D. (1997) Observations and predictions of arctic climatic change, potential effects on marine mammals. Arctic 50, 308 322.

Vanderlaan A.S.M. and Taggart C.T. (2007) Vessel collisions with whales: the probability of lethal injury based on vessel speed. Marine Mammal Science 23, 144-156.

Vanderlaan A.S.M., Taggart C.T., Serdynska A.R., Kenney R.D. and Brown M.W. (2008) The risk of lethal encounters: vessels and whales in the Bay of Fundy and on the Scotian Shelf. Endangered Species Research 4, 283-297.

and

Würsig B., Reeves R.R. and Ortega-Ortiz J.G. (2002) Global climate change and marine mammals. In Evans P.G.H. and Raga J.A. (eds) Marine mammals - biology and conservation. New York, NY: Kluwer Academic/Plenum Publishers, pp. 589-608.

\section{Correspondence should be addressed to:} P.G.H. Evans

Sea Watch Foundation, Ewyn y Don, Bull Bay, Amlwch, Anglesey LL68 9SD, UK email: peter.evans@bangor.ac.uk 